Review

\title{
A better understanding of traditional uses of Careya arborea Roxb.: Phytochemical and pharmacological review
}

\author{
Nupur Ambardar, Vidhu Aeri* \\ Department of Pharmacognosy and Phytochemistry, Faculty of Pharmacy, Jamia Hamdard, Hamdard University, New Delhi-110062, \\ India
}

\begin{abstract}
Careya arborea Roxb. (Lecythidaceae) is a significant medicinal plant known as kumbhi in Ayurveda. Though, most of the plant parts are used in traditional systems of medicine, bark and leaves constitute the important medicinal parts. The present review gives an account of the updated information on its phytochemical and pharmacological properties. The review reveals that numerous phytochemical constituents have been isolated from the plant possessing hepatoprotective, antioxidant, antimicrobial, anticoagulant, analgesic, antidiarrhoeal and various other important activities. Leaves are used in filaria, colic, loose motions and ulcers. Bark is used as an antipyretic, abortifacient, antipruritic and in smallpox, urinary discharges and rheumatic pain. Since last few decades, extensive exploration has been done to establish the biological activities and pharmacology of the extracts and plentiful chemical constituents including flavonoids, tannins, alkaloids, terpenoids and many other have been isolated.
\end{abstract}

Keywords Careya arborea, kumbhi, phytoconstituents, pharmacological activities

\section{INTRODUCTION}

Careya arborea Roxb., commonly known as wild guava, is a medium sized deciduous tree; exhibiting dark grey colour and exfoliating in thin strips. It is widely available in India, Ceylon, Malay and Peninsula.

The word Lecythidaceae means large tropical trees bearing large fruits with woody skins (wikipedia.org). Lecythidaceae is a family of tropical trees and consists of about 20 different genera and 450 different species. The family is generally concentrated in the wet regions of tropical South America, with some genera in Africa and Asia.

The stem bark is used in the treatment of tumours, bronchitis, epileptic fits and skin diseases (Kirtikar et al., 1975). It is also used as a remedy for diarrhoea (Sikarwar et al., 1994), dysentery with bloody stools and ear pain (Bhandary et al., 1995; Girach et al., 1994). It is a leech repellent, fish poison and antivenin activities have been also reported in the literature (John 1984; Selavanayahgam et al., 1994; Talapatra, 1981).

\section{Geographical source}

A deciduous tree found throughout India up to an altitude of $1,500 \mathrm{~m}$ and in Andaman Islands. It is planted in gardens and roadsides for its large conspicuous leaves and showy flowers and fruits (Kumar et al., 2010; Sharma et al., 1996).

\section{Morphology}

A handsome tree up to $20 \mathrm{~m}$ in height with a spreading crown; leaves are alternate, $15-30 \mathrm{~cm}$ long and $7.5-15 \mathrm{~cm}$ wide, broadly obovate or oblong-ovate, apex rounded, obtuse or shortly acuminate, margins are crenate- denticular, rather

*Correspondence: Vidhu Aeri

E-mail: vidhuaeri@yahoo.com

Received May 9, 2013; Accepted November 12, 2013; Published

November 30, 2013

doi: http://dx.doi.org/10.5667/tang.2013.0013

(C)2013 by Association of Humanitas Medicine membranous, glabrous, 10 - 12 pairs of lateral leaves; petiole is $0-1.8 \mathrm{~cm}$, long, stout and margined, crowded at the ends of the branches, penninerved, not dotted and are red when young. Flowers are large and handsome, in racemes or interrupted spikes, white-pink or yellowish white, $6.3-9 \mathrm{~cm}$ across, foetid, born in thick swollen hard terminal spikes each with a central elliptic bract and two linear lateral ones, showy, crowned with persistent calyx, ill smelling and sessile. Fruits are large, globose, fleshy, and indehiscent and are crowned with the calyx-limb and are $6.3-7.5 \mathrm{~cm}$ in diameter. Seeds have large embryo and obsolete cotyledons nesting in fleshy pulp (Parrotta et al., 2001).

\section{Physical Evaluation}

The physical evaluation of Careya arborea bark indicated: total ash $(12 \%)$, sulphated ash $(9.49 \%)$, water soluble ash $(2 \%)$, acid insoluble ash $(0.9 \%)$, water soluble extractive value $(16 \%)$, alcohol soluble extractive value $(7.2 \%)$ and loss on drying (14\%) (Wadkar et al., 2009).

\section{Traditional Uses}

Careya arborea as a whole plant and different parts has a long history of being used for a variety of medicinal uses (Table 1).

\section{Phytochemical Work}

Extensive phytochemical work has been carried out on Careya arborea, which indicated the presence of different classes of phytoconstituents, justifying the traditional uses of plant (Table 2).

\section{Pharmacological Work}

The phytochemical investigations revealed the presence of a maximum number of phytoconstituents in methanolic and ethanolic extract of bark and whole plant. The literature survey reported a number of biological activities attributed to flavonoids present in these extracts (Table 3 ). 
Table 1. Traditional uses of Careya arborea Roxb.

\begin{tabular}{|c|c|}
\hline Part used & Uses \\
\hline \multirow{2}{*}{ Whole plant } & $\begin{array}{l}\text { Astringent, demulcent, antipyretic, antipruritic, in cough, cold and eruptive } \\
\text { fevers Smallpox (Pal et al., 1999) }\end{array}$ \\
\hline & $\begin{array}{l}\text { Snake bite (Bhandary, 2000-2001; Chandra et al., 1989; } \\
\text { Jain, 1970) }\end{array}$ \\
\hline \multirow[t]{2}{*}{ Fruits } & Cold and cough (Kapoor and Kapoor, 1980) \\
\hline & Digestion promoter (Ahmed, 1982; Iyengar, 1986; Shah, 1982) \\
\hline \multirow{5}{*}{ Flowers } & $\begin{array}{l}\text { Aphrodisiac } \\
\text { Acrid, cures 'Kapha', demulcent in cough and cold } \\
\text { Tonic (Borthakur et al., 1996; Upadhye et al., 1994) }\end{array}$ \\
\hline & Vaginal ruptures \\
\hline & Fever (Rai et al., 1992) \\
\hline & Colic and loose motions (Prakash and Mehrotra, 1991) \\
\hline & Cold and Cough (Bedi, 1978; Shah, 1983) \\
\hline Calyx & Filaria (Mohan and Singh, 1996) \\
\hline Seeds & Colic and loose motions (Kumar and Pullaiah, 1999) \\
\hline \multirow{2}{*}{ Leaves } & Fever and swellings (Maheshwari, 1986) \\
\hline & Ulcers and skin diseases (Sharma, 1985) \\
\hline Twig & Leech repellent (John, 1984) \\
\hline \multirow{2}{*}{ Gum exudates } & Jaundice after delivery (Samvatsar, 2000) \\
\hline & Tongue ulcers (Girach and Aminuddin, 1995) \\
\hline \multirow{4}{*}{ Stem bark } & Constipation (Singh, 1993) \\
\hline & Diarrhoea (Rama Rao, 1999) \\
\hline & Skin diseases (Joshi, 1980) \\
\hline & $\begin{array}{l}\text { Dysentry } \\
\text { In asthma, dental diseases and snake bite (Kothari and Londhe, 1999) }\end{array}$ \\
\hline Stem sap & Menorrhegic (Pandey, 1991) \\
\hline Root & Astringent (Parinitha, 2004) \\
\hline \multirow{11}{*}{ Bark } & Washing and cleaning abscesses, boils, ulcers and diarrhoea \\
\hline & Ear pain (Bhandary et al., 1995) \\
\hline & Skin diseases (Malhotra and Moorthy, 1973) \\
\hline & Antipyretic, antipruritic and eruptive fever (Singh and Aswal, 1992) \\
\hline & Smallpox and stomach disorders (Sadhale, 1991) \\
\hline & Wound healing and body pain (Mohapatra, 1991) \\
\hline & $\begin{array}{l}\text { Astringent and demulcent } \\
\text { Cough and Cold } \\
\text { Alexiteric, anthelminthic and in urinary discharges } \\
\text { Rheumatic pain and diarrhoea (Jain, 1965) }\end{array}$ \\
\hline & $\begin{array}{l}\text { Eye complaints } \\
\text { Abortifacient (Mohanty, 1999) }\end{array}$ \\
\hline & Asthma, dental diseases and snake bite \\
\hline & Tumors, dyspepsia, bronchitis and colic \\
\hline & $\begin{array}{l}\text { Coarse fibre for cordage ropes, cloth sacking and saddle making } \\
\text { (Mukherjee and Ray, 1980; Row and Sastry, 1964) }\end{array}$ \\
\hline
\end{tabular}

\section{Hepatoprotective and In vivo antioxidant effects}

The methanolic extract of Careya arborea (MECA) stem bark was evaluated for its hepatoprotective and antioxidant effects in wistar albino rats. The hepatotoxicity was induced by carbon tetrachloride $\left(30 \mathrm{CCl}_{4}, 1 \mathrm{ml} / \mathrm{kg}\right.$ b.w in liquid paraffin 3 doses (i.p) at $72 \mathrm{~h}$ interval).The MECA at the doses of 50, 100 and $200 \mathrm{mg} / \mathrm{kg}$ and silymarin $25 \mathrm{mg} / \mathrm{kg}$ was administered to the $\mathrm{CCl}_{4}$ treated rats. Analytical parameters like serum transaminase (GOT, GPT), Alkaline Phosphatases (ALP), bilirubin, uric acid and total protein were measured in the rats induced hepatotoxicity by $\mathrm{CCl}_{4}$. The effects of the extract on lipid peroxidation (LPO), enzymatic antioxidant (Superoxide dismutase (SOD) and catalase (CAT), and nonenzymatic antioxidant (Glutathione (GSH), Vitamin $\mathrm{C}$ and Vitamin E were estimated. The MECA and silymarin produced significant $(p<$
0.05) hepatoprotective effect by decreasing the activity of serum enzymes, bilirubin, uric acid, and lipid peroxidation and significantly $(p<0.05)$ increased the levels of SOD, CAT, GSH, vitamin $C$, vitamin $E$ and protein in a dose dependent manner. From these results, it was suggested that MECA possess potent hepatoprotective and antioxidant activities (Kumar et al., 2005).

\section{Antimicrobial and antioxidant activities}

Antimicrobial activities of MECA were carried out using disc diffusion methods with Gram positive and Gram negative bacteria and some fungal species. MECA showed broadspectrum antimicrobial activity against all tested microorganisms. antimicrobial activity against all tested microorganisms. Antioxidant and free radical scavenging activities of MECA was assessed by using 1,1-diphenyl-2- 
Table 2. Phytochemical investigation of Careya arborea Roxb.

\begin{tabular}{|c|c|c|}
\hline Plant part & Type of extract & Chemical constituents \\
\hline Whole plant (excluding root) & $50 \%$ methanolic extract & Tannins (Atal, 1978) \\
\hline \multirow{3}{*}{ Flowers } & $\begin{array}{l}\text { Petroleum ether, benzene and chloroform } \\
\text { extracts }\end{array}$ & Steroids and triterpenoids \\
\hline & Chloroform and ethanolic extracts & Phenols \\
\hline & Ethanolic extract & Tannins (Shantha, 1987) \\
\hline \multirow{3}{*}{ Seeds } & \multirow{3}{*}{$\alpha$-spinasterol, $\alpha$ - spinasterone } & $\begin{array}{l}\alpha \text {-spinasterol, } \alpha \text {-spinasterone } \\
\alpha \text {-spinasterol, } \Delta^{22} \text { - stigmastenol (Mahato and } \\
\text { Dutta, 1972) }\end{array}$ \\
\hline & & $\begin{array}{l}\text { Triterpenoids: Barringtogenol C, } \\
\text { Barringtogenol D, } 16 \text { desoxy barringtogenol } \\
\text { (Mahato and Dutta, 1973) }\end{array}$ \\
\hline & & Starch (Soni, 1991) \\
\hline \multirow{6}{*}{ Leaves } & \multirow{4}{*}{ Petroleum ether extract } & Taraxerol (Mahato, 1967) \\
\hline & & $\begin{array}{l}\text { Careyagenolide, maslinic acid, } 2 \alpha \text { hydroxy } \\
\text { ursolic acid (Das and Mahato, 1982) }\end{array}$ \\
\hline & & $\begin{array}{l}\mathrm{n} \text {-hexacosanol, } \alpha \text {-spinasterol, taraxerol, } \\
\text { taraxeryl acetate, } \beta \text {-sitosterol, ellagic acid } \\
\text { and quercitin (Gupta, 1975) }\end{array}$ \\
\hline & & Triterpene ester- careaborin (Talapatra, 1981) \\
\hline & \multirow{2}{*}{ Ethanolic extract } & Tannins (Gupta, 1981) \\
\hline & & $\begin{array}{l}\text { Absence of saponins, alkaloids and } \\
\text { flavonoids (Kapoor, 1969) }\end{array}$ \\
\hline \multirow{3}{*}{$\begin{array}{l}\text { Leaves (Forming feed of livestock in North- } \\
\text { eastern hill region) }\end{array}$} & & $\begin{array}{l}\text { Crude protein, ether extract, crude fibre, ash, } \\
\text { nitrogen free extract, organic matter (Varma, } \\
\text { 1982) }\end{array}$ \\
\hline & & Nitrogen (George, 1957) \\
\hline & & $\begin{array}{l}\text { Energy as fodder } 902.4 \mathrm{Kcal} / \mathrm{Kg} \text {, } \\
\text { metabolizable energy } 1543.4 \mathrm{Kcal} / \mathrm{Kg} \text { and } \\
\text { digestible energy } 1789.6 \mathrm{Kcal} / \mathrm{Kg} \text { (Joshi, } \\
1976 \text { ) }\end{array}$ \\
\hline \multirow{5}{*}{ Bark } & & Sterols and terpenes (Bhattacharjee, 1969) \\
\hline & & $\begin{array}{l}\text { Absence of alkaloids, saponins and } \\
\text { flavonoids (Kapoor, 1972) }\end{array}$ \\
\hline & & $\begin{array}{l}\text { Saponins and tannins (Joshi and Sabnis, } \\
\text { 1989) }\end{array}$ \\
\hline & & $\begin{array}{l}\text { Pyroligenous acid and other components } \\
\text { (Kedare and Tendolkar, 1953) }\end{array}$ \\
\hline & & $\begin{array}{l}\text { Presence of steroids, terpenoids, alkaloids, } \\
\text { flavonoids and saponins }\end{array}$ \\
\hline
\end{tabular}

picryl-hydrazyl radical (DPPH), superoxide anion radical, nitric oxide radical and hydroxide radical scavenging assays. The antioxidant activity of MECA increased in a concentrationdependent manner. The results indicated that the MECA can be a potential source of natural antimicrobial and antioxidant agents (Kumar et al., 2006).

\section{CNS activity}

The methanol extract of barks of Careya arborea was used to investigate central nervous system (CNS) activity in Swiss albino mice and Wistar albino rats. General behaviour, exploratory behaviour, muscle relaxant activity and phenobarbitone sodium-induced sleeping time were studied. Methanol extract of barks at 100 and $200 \mathrm{mg} / \mathrm{kg}$ caused a significant reduction in the spontaneous activity (general behavioural behaviour), remarkable decrease in exploratory behavioural pattern, a reduction in muscle relaxant activity, and also significantly potentiated phenobarbitone sodium- induced sleeping time. The results suggest that methanol extract of Careya arborea exhibit CNS depressant activity in tested animal models (Kumar et al., 2008).

\section{Antitumor and antioxidant activity}

The methanol extract of bark was evaluated for the anticancer potentials against Dalton's lymphoma ascites (DLA)-induced ascitic and solid tumors. The methanol extract of its bark given orally to mice at the dose of 250 or $500 \mathrm{mg} / \mathrm{kg}$ body weight for 10 days caused significant reduction in percent increase in body weight, packed cell volume and viable tumor cell count when compared to the mice of DLA control group. Restoration of haematological and biochemical parameters towards normal was also observed. Histological observations of liver and kidney also indicated repair of tissue damage caused by tumor inoculation. The extract at the dose of 5 or $25 \mathrm{mg} / \mathrm{kg}$ body weight given i.p daily for 14 days significantly reduced the solid tumor volume induced by DLA cells (Natesan et al., 2007).

\section{Antidiarrhoeal activity}

The methanol extract of the Careya arborea Roxb. bark significantly reduced castor oil-induced diarrhoea in mice. This effect supports the local traditional use of the plant against 
Table 3. Pharmacological actions of Careya arborea Roxb.

\begin{tabular}{|c|c|c|}
\hline Plant part & Type of extract & Pharmacology \\
\hline Trunk bark & 90 and $10 \%$ methanolic extract & $\begin{array}{l}\text { No sedation and analgesia in mice } \\
\text { No effect on B.P and respiration in cats } \\
\text { No direct action/ antagonism on the isolated } \\
\text { intestine of rabbit and guinea pig, isolated } \\
\text { uterus of guinea pig, frog rectus abdominis } \\
\text { muscle and isolated frog heart (Bhatnagar et } \\
\text { al., 1961) }\end{array}$ \\
\hline Whole plant (excluding root) & $50 \%$ ethanolic extract & $\begin{array}{l}\text { No activity when screened for antibacterial/ } \\
\text { antifungal/ antiprotozoal/ } \\
\text { antiviral/ hypoglycaemic/ anticancer } \\
\text { and diuretic activities Phenols } \\
\text { Tannins (Shantha, 1987) } \\
\text { Effect on respiration, nictating membrane, } \\
\text { CVS and CNS of experimental animals; } \\
\text { isolated guinea pig ileum and rat uterus } \\
\text { (Bhakuni et al., 1969) }\end{array}$ \\
\hline Stem bark & $\begin{array}{l}\text { Petroleum ether extract } \\
\alpha \text { - spinasterol, } \alpha \text { - spinasterone }\end{array}$ & $\begin{array}{l}\alpha \text { - spinasterol, } \alpha \text { - spinasterone } \\
\alpha \text {-spinasterol, } \Delta^{22} \text { - stigmastenol (Mahato and } \\
\text { Dutta, 1972) } \\
\text { Triterpenoids: Barringtogenol C, } \\
\text { Barringtogenol D, 16 desoxy barringtogenol } \\
\text { (Mahato and Dutta, 1973) } \\
\text { Starch (Soni, 1991) } \\
\end{array}$ \\
\hline Leaves & Ethanolic extract & $\begin{array}{l}\text { Taraxerol (Mahato, 1967) } \\
\text { Careyagenolide, maslinic acid, } 2 \alpha \text { hydroxy } \\
\text { ursolic acid (Das and Mahato, 1982) } \\
\text { n-hexacosanol, } \alpha \text {-spinasterol, taraxerol, } \\
\text { taraxeryl acetate, } \beta \text {-sitosterol, ellagic acid } \\
\text { and quercitin (Gupta, 1975) } \\
\text { Triterpene ester- careaborin (Talapatra, 1981) } \\
\text { Tannins (Gupta, 1981) } \\
\text { Absence of saponins, alkaloids and } \\
\text { flavonoids (Kapoor, 1969) }\end{array}$ \\
\hline $\begin{array}{l}\text { Leaves (Forming feed of livestock in North- } \\
\text { eastern hill region) }\end{array}$ & & $\begin{array}{l}\text { Crude protein, ether extract, crude fibre, ash, } \\
\text { nitrogen free extract, organic matter (Varma, } \\
\text { 1982) } \\
\text { Nitrogen (George, 1957) } \\
\text { Energy as fodder } 902.4 \mathrm{Kcal} / \mathrm{Kg}, \\
\text { metabolizable energy } 1543.4 \mathrm{Kcal} / \mathrm{Kg} \text { and } \\
\text { digestible energy } 1789.6 \mathrm{Kcal} / \mathrm{Kg} \text { (Joshi, } \\
\text { 1976) }\end{array}$ \\
\hline Bark & & $\begin{array}{l}\text { Sterols and terpenes (Bhattacharjee, 1969) } \\
\text { Absence of alkaloids, saponins and } \\
\text { flavonoids (Kapoor, 1972) } \\
\text { Saponins and tannins (Joshi and Sabnis, } \\
\text { 1989) } \\
\text { Pyroligenous acid and other components } \\
\text { (Kedare and Tendolkar, 1953) } \\
\text { Presence of steroids, terpenoids, alkaloids, } \\
\text { flavonoids and saponins }\end{array}$ \\
\hline
\end{tabular}

diarrhoea (Saha et al., 2003).

\section{Analgesic activity}

Isolation of the bark of Careya arborea Roxb. bark afforded piperine- an alkaloid chemically known as 1-5-(1,3benzodioxol-5-yl)-1-oxo-2,4-pentadienylpiperidine. At oral doses of 10,20 and $30 \mathrm{mg} / \mathrm{kg}$ body weight, piperine exhibited inhibition of acetic acid induced writhing in mice repectively. At doses of 20 and $30 \mathrm{mg} / \mathrm{kg}$ body weight, the compound also showed prolongation of tail flicking time of mice $30 \mathrm{~min}$ after the treatments determined by the radiant heat method. Thus, the isolated alkaloid was found to possess significant central and peripheral analgesic activity (Ahmed, 2002).

\section{Cytotoxic and antioxidant activity}

The successive chloroform and ethyl acetate extracts and crude $50 \%$ methanol bark extract were evaluated for cytotoxic and antioxidant activity. The extracts exhibited potent cytotoxicity against cancerous RD, Hep- 2 and HeLa cell lines. They were found to be safe against the normal Vero cell line. The methanol and aqueous extracts possessed strong antioxidant activity against many oxidants in the in-vitro antioxidant screening. The results show strong cytotoxic and antioxidant properties, which are due to high total phenol content present in the plant. 


\section{Anticoagulant activity}

Methanolic extract of Careya arborea bark was evaluated for anticoagulant activity by the assay of activated partial thromboplastin time (aPTT), Prothrombin time (PT), and thrombin time (TT). Bark extract caused significant $(p<0.05)$ increase in aPTT, PT and TT at all doses were almost equivalent to the response of warfarin. Prolongation in PT may be due to decrease in coagulation factors such as VIII, IX, XI, XII and prekallikrein involved in intrinsic pathway (SubhadraDevi et al., 2011).

\section{CONCLUSION}

Use of herbal medicinal plants has been distinctive in our lives right from the primitive period till today and provided us with the data on the use of plants or plant products as therapeutic agents in treating various ailments by virtue of their phytoconstituents (Chahlia et al., 2009; Saikia et al., 2006; Srivastav et al., 2011).

Careya arborea Roxb. is an important medicinal plant. Extensive literature survey revealed its phytochemical constituents and pharmacological potential as an important traditional drug. The drug is enriched with flavonoids, tannins, terpenoids and sterols. The plant exhibits many pharmacological activities like antimicrobial, antioxidant, antitumor, analgesic, hepatoprotective, antidiarrhoeal, anticoagulant and diuretic properties. However, a systematic phytochemical investigation is required to standardize the drug with reference to the presence of flavonoids with suitable marker compounds. A systematic phytochemical work is under progress in Authors' laboratory.

\section{ACKNOWLEDGEMENTS}

The authors are thankful to National Medical Library, New Delhi; NISCAIR, New Delhi; CDRI, Lucknow; NBRI, Lucknow and to the HAH Central Library, Jamia Hamdard, New Delhi, for providing literature survey facility to accomplish the work.

\section{CONFLICT OF INTEREST}

The authors have no conflicting financial interests.

\section{REFERENCES}

Ahmed J, Chaghtai SA. A study of tree flora of Bhopal with special reference to their medicinal values. Bull Med Ethnobot Res. 1982;3:114-152.

Ahmed M, Rahman MW. Analgesic principle from the bark of Careya arborea. Die Pharmazie. 2002;57:698-701.

Aswal BS, Goel AK, Kulshreshtha DK, Mehrotra BN, Patnaik GK. Screening of Indian plants for biological activity: Part XV. Indian J Exp Biol. 1996;34:444-467.

Atal CK, Srivastava JB, Wali BK, Chakravarty RB, Dhawan BN, Rastogi RP. Screening of Indian plants for biological activity: Part VIII. Indian J Exp Biol. 1978;16:330-349.

Bedi SJ. Ethnobotany of Ratan Mahal hills, Gujarat, India.

\section{Econ Bot. 1978;32:278-284.}

Bhakuni DS, Dhar ML, Dhar MM, Dhawan BN, Mehrotra BN. Screening of Indian plants for biological activity: Part II. Indian J Exp Biol. 1969;7:250-262.

Bhandary MJ, Chandrashekhar KR, Kaveriappa KM. Medical ethnobotany of the Siddis of Uttar Kannada district, Karnataka, India. J Ethnopharmacol. 1995;47:149-158.

Bhandary MJ, Chandrashekhar KR. Treatment for poisonous snake bites in the ethnomedicine of coastal Karnataka. J Med Aromat Plant Sci. 2000;22:505-510.

Bhatnagar SS, Santapau H, Fernandes F, Kamat VN, Dastoor NJ, Rao TSN. Physiological activity of Indian Medicinal plants. J Sci Ind Res. 1961;20:1-24.

Bhattacharjee AK, Das AK. Phytochemical screening of some Indian plants. Quart J Crude Drug Res. 1969;9:1408-1412.

Borthakur SK, Nath K, Gogoi P. Herbal remedies of the Napalese of Assam. Fitoterapia. 1996;67:231-237.

Chahlia N. Effect of capparis decidua on hypolipidemic activity in rats. J Med Plants Res. 2009;3:481-484.

Chandra K, Pandey BN, Sinha GN, Pandey P. Medicinal plants of Rajgir, Bihar. Bull Med Ethnobot Res. 1989;10:124-161.

Das MC, Mahato SB. Triterpenoid sapogenols from the leaves of Careya arborea: Structure of careyagenolide. Phytochemistry. 1982;21:2069-2073.

George J, Kohli RC. Nitrogen content of the leaves of some Indian trees. Indian For. 1957;83:287-288.

Girach RD, Aminuddin S, Siddiqui PA, Khan SA. Traditional plant remedies among the kondh of district of Dhenkanal (Orissa). Intl J Pharmacol. 1994;323:274-283.

Girach RD, Aminuddin. Ethnomedicinal uses of plants among the tribals og Singhbhum district, Bihar, India. Ethnobotany. 1995;7:103-107.

Gupta RK, Chakraborty NK, Dutta TR. Crystalline constituents from Careya arborea Roxb. Indian J Pharm. 1975;376:161-162.

Gupta RK. Tannin bearing plants of India from denuded wastelands. J Econ Tax Bot. 1981;2:139-155.

Iyengar MA, Bhat KG, Nayak SGK, Rajgopal PK, Nanda A. Survey of medicinal flora of South Kanara, Series I. Indian Drugs. 1986;24:69-73.

Jain SK, Tarafder CR. Medicinal plant-lore of Santhals. Econ Bot. 1970;24:241-278.

Jain SK. Medicinal plantlore of tribals of Bastar. Econ Bot. 1965;19:236-250.

John D. One hundred useful raw drugs of the Kani tribes of Trivandrum forest division, Kerela, India. Int J Crude Drug Res. 1984;22:17-39.

Joshi DC. Energy evaluation of forages. Indian Vet $\mathrm{J}$. 
1976;53:873-877.

Joshi MC, Patel MB, Mehta PJ. Some folk medicines of Dangs, Gujarat. Bull Med Ethnobot Res. 1980;1:8-24.

Joshi MC, Sabnis SD. A phytochemical study of South Gujarat forest plants with special reference to the medicinal and ethnobotanical interest. Bull Med Ethnobot Res. 1989;10:61-82.

Kapoor LD, Singh A, Kapoor SL, Srivastava SN. Survey of Indian plants for saponins, alkaloids and flavonoids. I Lloydia. 1969;32:297-304.

Kapoor LD, Srivastava SN, Singh A, Kapoor SI, Shah NC. Survey of Indian plants for saponins, alkaloids and flavonoids, III, Lloydia. 1972;35:288-295.

Kapoor SL, Kapoor LD. Medicinal plant wealth of the Karimnagar district of Andhra Pradesh. Bull Med Ethnobot Res. 1980;1:120-144.

Kedare BS, Tendolkar GS. Ash analysis of some hardwood species of the State of Bombay. J Sci Ind Res. 1953;12:125-126.

Kirtikar KR, Basu BD. Indian medicinal plants. $2^{\text {nd }}$ ed. (Dehradun, India: Bishen Singh Mahendra Pal Singh), pp. 894895, 1975.

Kothari MJ, Londhe AN. Ethnobotany in human health care of Chikhaldara Amravati district in Maharashtra state, India. J Econ Tax Bot. 1999;23:273-281.

Kumar BN, Swamy BM. Review on Careya arborea Roxb. Int J Ayurveda \& Pharmacy. 2010;1:306-315.

Kumar RS Sivakumar T, Gupta M, Mazumdar UK. Hepatoprotctive and in vivo antioxidant effects of Careya arborea against carbon tetrachloride induced liver damage in rats. Inter J Mole Med Ad Sci. 2005;4:418-24.

Kumar RS, Sivakumar T, Sundaram RS, Sivakumar P, Nethaji R, Gupta M. Antimicrobial and antioxidant activities of Careya arborea Roxb. Stem bark. Iranian J Pharmacol Therap. 2006;5:35-41.

Kumar RS, Sundaram RS, Sivakumar P, Nethaji R, Senthil V, Murthy NV. CNS activity of the methanol extracts if Careya arborea in experimental animal model. Bangladesh J Pharmacol. 2008;3:36-43.

Kumar TDC, Pullaiah T. Ethno- medicinal uses of some plants of Mahabubnagar district, A.P., India. J Econ Tax Bot. 1999;23:341-345.

Mahato SB, Banerjee SK, Chakravarti RN. Taraxerol from Careya arborea. Bull Calcutta Sch Trop Med. 1967;5:8-9.

Mahato SB, Dutta NL, Chakravarti RN. Triterpenes from Careya arborea. Structure of careyagenol D. J Indian Chem Soc. 1973;50:254-259.

Mahato SB, Dutta NL. Sterols from Careya arborea Roxb. Phytochemistry. 1972;11:2116-2117.

Maheshwari JK, Kalakoti BS, Lal B. Ethnomedicine of Bhil tribe of Jhabua district, M.P. Ancient Sci Life. 1986;5:255-261.
Malhotra SK, Moorthy S. Some useful Medicinal plants of Chandrapur district. Bull Bot Surv India. 1973;15:13-21.

Mohan K, Singh AK. Ethno-medico-botany of Tharus. Adv Plant Sci. 1996;9:1-16.

Mohanty RB, Rout MK. Ethnobotany of Careya arborea Roxb. Some noteworthy folk uses in Orissa. J Econ Tax Bot. 1999;23:505-508.

Mohapatra AK. Ethnopharmacological notes on Pauri-Bhuinya tribe of Orissa. Indian For. 1991;117:126-130.

Mukherjee K, Ray LN. Screening of some Indian plant species. Quart J Crude Drug Res. 1980;18:77.

Natesan S, Badami S. Antitumor and antioxidant status of the methanol extract of Careya arborea bark against Dalton's lymphoma ascites- induced ascetic and solid tumor in mice. J Pharmacol Sciences. 2007;103:2-23.

Pal DC, Guha A, Sen R. Medicinal plants and plant products used in children diseases among aboriginals in India. J Econ Tax Bot. 1999;23:121-130.

Pandey RK, Bajpai AK, Bhattacharya P. Some unique folk ,medicines of Baiga tribes of Mandla district of M.P. J Trop For. 1991;7:62-66.

Parinitha M, Harish GU, Vivek NC, Mahesh T, Shivanna MB. Ethno-botanical wealth of Bhadra wild life sanctuary in Karnataka. Indian J Trad Knowl. 2004;3:37-50.

Parrotta JA. Healing plants of peninsular India. (Wallingford, U K: CAB International), pp. 449-451, 2001.

Prakash V, Mehrotra BN. Ethnomedical uses of some plants among Garos of Meghalya. Ethnobotany. 1991;3:41-45.

Rahman MT, Khan OF, Saha S, Alimuzzaman M. Antidiarrhoeal activity of the bark extract of Careya arborea Roxb. Fitotherapia. 2003;74:116-118.

Rai MK, Nonhare BP. Ethnomedical studies of Chhindwara, M.P-II. Indian Med. 1992;4:7-10.

Rama Rao NR, Rajendran A, Henry AN. Phyto-zootherapy of the tribes of Andhra.Pradesh. J Econ Tax Bot. 1999;23:331-335.

Row LR, Sastry CSP. Chemical examination of Careya arborea. Roxb. Indian J Chem. 1964;2:510.

Sadhale A, Majumdar AM, Pendse GS. Ethnobotanical studies of sacred grove at Ajjiwali, Pune district. J Econ Tax Bot. 1991;15:167-172.

Saikia B. Ethnomedicinal plants from Gohpur of Sonitpur district, Assam. Indian J Tradit Knowl. 2006;5:529-530.

Samvatsar S, Diwanji VB. Plant sources for the treatment of jaundice in the tribals of Western M.P of India. J Ethanopharmacol. 2000;73:313-316.

Selvanayahgam ZS, Gnanevedhan G, Balakrishna K. Antisnake venom botanicals from ethno medicine. J Herbs Spices Med 
Plants. 1994;2:45-100.

Shah GL, Gopal GV. An Ethnobotanical profile of the Dangies. J Econ Tax Bot. 1982;3:355-364.

Shah GL, Yadav SS, Badri Nath V. Medicinal plants from Dhanu Forest division in Maharashtra state. J Econ Tax Bot. 1983;4:141-151.

Shantha TR, Pasupathy S, Yoganarasimhan SN. Identification, macro-, microscopic and physicochemical details of a market sample of padmaka (Careya arborea Roxb.) Indian J For. 1987;10:131-139.

Sharma PC, Murthy KS, Bhat AV, Narayanappa D, Kishore P. Medicinal -lores of Orissa-I. Skin diseases. Bull Med Ethnobot Res. 1985;6:93-101.

Sharma PV. Classical use of medicinal plants. $1^{\text {st }}$ ed. (Varanasi, India: Chowkhambha Bharati Academy), 1996.

Sikarwar RLS, Bajpai AK, Painuli RM. Plants used as veterinary medicines by aboriginals of Madhya Pradesh, India. Intl. J. Pharmacognosy. 1994;3:251-255.

Singh PB, Aswal BS. Medicinal plants of Himachal Pradesh used in Indian Pharmaceutical industry. Bull Med Ethnobot Res. 1992;13:172-208.

Singh VK, Dhar U. Folk medicines of Orissa: Keonjhar forests. Glimpses Plant Res. 1993;1:103-107.
Soni PL. Forest source of starch and its derivatives. Indian J MFP. 1991;1:86.

Srivastav S, Singh P, Mishra G, Jha KK, Khosa RL. Achyranthes aspera-an important medicinal plant: A review. J Nat Prod Plant Resourc. 2011;1:1-14.

Subhadradevi V, Christy J, Asok Kumar K, Umamaheswari M, Sivashanmugham AT. Induction of apoptosis and cytotoxic activities of methanolic extract of Careya arborea Roxb. Bark. Pharmacie Glovale. 2010;1:1-4.

Talapatra B, Basak A, Talapatra SK. Terpenoids and related compounds Part XX. Careaborin, a new triterpene ester from the leaves of Careya arborea Roxb. J Indian Chem Soc. 1981;58:814-815.

Talapatra B, Basak BA, Talapatra SK. Terpenoids and related compounds Part XX. Careaborin, a new triterpene ester from the leaves of Careya arborea Roxb. J Indian Chem Soc. 1981;58:814-815.

Upadhye AS, Vartak VD, Kumbhojkar MS. Ethno-medicobotanical studies in Western Maharashtra, India. Ethnobotany. 1994;6:25-31.

Varma A, Yadav BPS, Sampath KT, Roy DJ. Chemical composition of common fodder tree leaves, shrubs and epiphytes in North-eastern hill region. Indian J Anim Sci. 1982;52:859-865.

Wadkar K, Magdum Chandrakant S. Pharmacognostic profiles of bark of Careya arborea Roxb. JPP. 2009;1:64-66. 